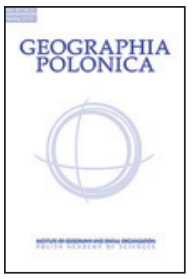

\title{
LARGE-SCALE MONITORING OF AIR POLLUTION IN REMOTE AND ECOLOGICALLY IMPORTANT AREAS
}

\author{
1 USDA Forest Service \\ Pacific Southwest Research Station \\ Riverside, CA 92507, USA \\ e-mail address: abytnerowicz@fs.fed.us \\ ${ }^{2}$ Environmental Systems \\ Research Institute \\ Redlands, CA 92373, USA \\ e-mail address: wfraczek@esri.com
}

Andrzej Bytnerowicz ${ }^{1}$ • Witold Frączek ${ }^{2}$

\begin{abstract}
New advances in air quality monitoring techniques, such as passive samplers for nitrogenous $(\mathrm{N})$ or sulphurous $(\mathrm{S})$ pollutants and ozone $\left(\mathrm{O}_{3}\right)$, have allowed for an improved understanding of concentrations of these pollutants in remote areas. Mountains create special problems with regard to the feasibility of establishing and maintaining air pollution monitoring networks, due to their complex topography and difficult access. Therefore, careful design of monitoring networks, selection of monitoring equipment, and a reliable workforce are essential for successful mountain monitoring campaigns. The USDA Forest Service team, in collaboration with various partners in Europe and North America, has conducted numerous monitoring campaigns in order to determine concentrations of $\mathrm{O}_{3}$, nitrogen dioxide $\left(\mathrm{NO}_{2}\right)$, ammonia $\left(\mathrm{NH}_{3}\right)$, nitric acid vapor $\left(\mathrm{HNO}_{3}\right)$, and sulphur dioxide $\left(\mathrm{SO}_{2}\right)$ in remote areas. These results, aided by geostatistical methodologies, have resulted in the creation of maps that are essential for a better understanding of the distribution of various air pollutants in the Carpathian Mountains (specifically, the Tatras, Retezat, and Bucegi ranges) in Europe; the Sierra Nevada (including Sequoia, Kings Canyon and Yosemite National Parks), the San Bernardino Mountains, the White Mountains, and Joshua Tree National Park in California; the Columbia Rivers Basin in Oregon; and the Athabasca Oil Sands Region in northern Alberta, Canada. Information on the concentrations and distribution of air pollutants which have been measured in those areas provides an understanding of their potential risks to human health, ecosystem health and sustainability, and ecosystem services.
\end{abstract}

\section{Key words}

monitoring - air pollution - forests - remote areas - mountains - human health $\bullet$ ecosystems - Europe $\bullet$ North America

\section{Introduction}

Air pollution can be defined as impurities in the air in the form of gases or aerosols that are added to the atmosphere. Air pollutants can be divided into two general classes of pollutant: primary pollutants, which are emitted directly into the atmosphere from stationary or mobile sources, and secondary pollutants, which are not directly emitted into the atmosphere but are generated there over time via chemical reactions (Finlayson-Pitts $\&$ Pitts 2000). Examples of primary gaseous air 
pollutants that have highly significant effects on human health include nitric oxide (NO), carbon monoxide $(\mathrm{CO})$, sulphur dioxide $\left(\mathrm{SO}_{2}\right)$, hydrogen fluoride (HF), and various volatile organic compounds (VOCs). Primary particulate pollutants are represented by smoke aerosols emitted from fires and power plants (with a large portion of black carbon and soot), and dust particles from cement plants or agriculture. Examples of secondary pollutants are ozone $\left(\mathrm{O}_{3}\right)$, nitrogen dioxide $\left(\mathrm{NO}_{2}\right)$, nitric acid vapor $\left(\mathrm{HNO}_{3}\right)$, peroxyacetyl nitrate (PAN), liquid aerosols $\left(\mathrm{H}_{2} \mathrm{SO}_{4}, \mathrm{HNO}_{3}\right)$, or particulate pollutants such as ammonium nitrate $\left(\mathrm{NH}_{4} \mathrm{NO}_{3}\right)$ or ammonium sulphate $\left(\mathrm{Na}_{2} \mathrm{SO}_{4}\right)$ (Seinfeld \& Pandis 1999).

From the perspective of the large-scale effects, tropospheric (ground-level) $\mathrm{O}_{3}$ is of major concern due to its high toxicity to humans and vegetation. Peak $\mathrm{O}_{3}$ concentrations in North America and Europe have been significantly reduced due to strict regulations primarily aimed at lowering emissions of $\mathrm{O}_{3}$ precursors ( $\mathrm{NOx}, \mathrm{CO}$, and $\mathrm{VOCs}$ ) from mobile sources by using reformulated gasoline and catalytic converters. However, because of increasing emissions of $\mathrm{O}_{3}$ precursors in the developing countries, global background concentrations have been rising (Sitch et al. 2007). $\mathrm{O}_{3}$ concentrations that are elevated to phytotoxic levels have been reported in forests of the San Bernardino Mountains (Miller 1992; Bytnerowicz et al. 2008) and the southwestern Sierra Nevada in California (Bytnerowicz, Tausz et al. 2002), areas surrounding Mexico City (Miller et al. 1994), the eastern United States (Neufeld et al. 2012), the Mediterranean Basin and Southern Alps (Millan et al. 1997), the Carpathian Mountains in Europe (Bytnerowicz, Godzik et al. 2004), and Southeast Asia (Wang \& Mauzerall 2004). It is predicted that by 2050 about $50 \%$ of global forests may be affected by potentially phytotoxic $\mathrm{O}_{3}$ concentrations greater than $60 \mathrm{ppb}$ (Fowler et al. 1999). The US Environmental Protection Agency (US EPA) is proposing lowering allowable concentrations of $\mathrm{O}_{3}$ for better protection of human health. The EPA is also proposing a new secondary standard for the protection of welfare, especially vegetation (EPA 2010). To implement that new standard, improved understanding of $\mathrm{O}_{3}$ distribution in remote areas is needed.

Reactive nitrogen consisting of various nitrogenous ( $N$ ) air pollutants creates an assortment of health and ecological problems. Biologically active and chemically reactive $\mathrm{N}$ compounds occur in the atmosphere and biosphere as inorganic chemically reduced forms ( $\mathrm{NHx}$ ) consisting of ammonia $\left(\mathrm{NH}_{3}\right)$ and ammonium ions $\left(\mathrm{NH}_{4}^{+}\right)$; inorganic chemically oxidised forms such as nitrous oxide $\left(\mathrm{N}_{2} \mathrm{O}\right)$, nitrogen pentoxide $\left(\mathrm{N}_{2} \mathrm{O}_{5}\right), \mathrm{NO} \mathrm{NO}_{2}, \mathrm{HNO}_{3}$, nitrous acid ( $\mathrm{HONO}$ ), peroxyacetyl' compounds such as peroxyacetyl nitrate (PAN), nitrate ions $\left(\mathrm{NO}_{3}{ }^{-}\right)$; and various organic compounds. Reactive $\mathrm{N}$ compounds of ecological significance are $\mathrm{NO}$ emitted mainly from internal combustion engines and industry; $\mathrm{NO}_{2}$ resulting from the oxidation of $\mathrm{NO} ; \mathrm{NH}_{3}$ emitted through natural biological processes and from agriculture, waste treatment, and industrial activities; $\mathrm{HNO}_{3}$ vapor, generated by photochemical reactions; and particulate $\mathrm{NO}_{3}$. and $\mathrm{NH}_{4}^{+}$that mainly result from reactions of $\mathrm{NH}_{3}$ with $\mathrm{HNO}_{3}$ (EPA 2009). Atmospheric deposition of $\mathrm{N}$ to ecosystems occurs as wet deposition (rain, fog, cloud, snow) of $\mathrm{NO}_{3}{ }^{-}$and $\mathrm{NH}_{4}{ }^{+}$; dry surface deposition of $\mathrm{HNO}_{3}, \mathrm{NH}_{3}$, and particulate $\mathrm{NO}_{3}$ and $\mathrm{NH}_{4}{ }^{+}$; and stomatal uptake of $\mathrm{NO}, \mathrm{NO}_{2}, \mathrm{NH}_{3}$, $\mathrm{HNO}_{3}$ (Hanson \& Lindberg 1991). In the Mediterranean climate (California) dry deposition of $\mathrm{N}$ dominates (Padgett et al. 1999). There are extensive areas of increased $\mathrm{N}$ deposition in Europe, North America, and Asia (Galloway et al. 2003). Sulfur dioxide is an important toxic air pollutant that may affect vegetation health and acidify forests and other ecosystems (Legge et al. 1998). Data on the spatial and temporal distribution of $\mathrm{N}$ and $S$ air pollutants are important for estimates of atmospheric dry deposition of $\mathrm{N}$ and $\mathrm{S}$ using inferential models (Hanson \& Lindberg 1991).

Information on the air pollution status in remote areas, especially in complex mountain terrain, is still insufficient. More information is needed for an understanding of the threats of toxic pollutants to the health of humans and sensitive plants, estimates of atmospheric deposition needed for the evaluation of critical loads for acidity and nutritional effects, the ground-testing of remotelyobtained data on air pollution concentrations, the verification of models describing the impacts of air pollution, and atmospheric deposition on forests and other ecosystems. To obtain this data, passive samplers have been successfully used for monitoring ecologically important air pollutants such as $\mathrm{O}_{3}, \mathrm{NOx}, \mathrm{NH}_{3}$, and $\mathrm{SO}_{2}$. They have achieved success due to their low cost, simple design and operation, low maintenance demands, lack of a need for electric power, the opportunity they provide for dense deployment, reliable results, 
and integration of long-term exposure regimes (Bytnerowicz et al. 2000). Aided by geostatistics, the results from air pollution monitoring networks can also be used for generating maps of air pollution distribution that are useful for scientists, air resource and land managers, and decision makers (Frączek et al. 2003).

This article provides an overview of the largescale air pollution monitoring campaigns conducted by a research team comprised of scientists from the USDA Forest Service and various research institutes and universities in Central Europe and North America. The results of these studies are illustrated with examples from California, the United States, and Alberta, Canada.

\section{Methodology}

Ogawa passive samplers were used for determinations of $\mathrm{O}_{3}, \mathrm{NO}_{2}, \mathrm{NOx}$, and $\mathrm{NH}_{3}$ (Koutrakis et al. 1993; Ogawa 2006). For determinations of $\mathrm{HNO}_{3}$ and $\mathrm{SO}_{2}$ the samplers developed by the USDA Forest Service were utilised (Bytnerowicz et al., 2005). Typically, samplers were exposed for 2-week periods during the summer season (June-October). Determinations of $\mathrm{O}_{3}, \mathrm{NO}_{2}, \mathrm{NOx}$, and $\mathrm{SO}_{2}$ concentrations were carried out as described by Arbaugh and Bytnerowicz (2003) and of $\mathrm{HNO}_{3}$ and $\mathrm{SO}_{2}$ by Bytnerowicz et al. (2007). Geostatistical Analyst, an extension of ArcGIS (ESRI) that generates predictive surfaces from data points using geostatistical tools and analysing the error of the resulting estimations, was utilised for creating maps of pollutant distributions by using numerous kriging and predictive tools (Johnstone et al. 2001).

\section{Results and Discussion}

Monitoring campaigns conducted in Central Europe in the 1990s started with studies under the auspices of the "US-Polish cooperative project on the status and long-term trends in forest ecosystems: climate, pollution, and forest health" research programme (Breymeyer 1997; Bytnerowicz 1997). As a result of these studies, $O_{3}$ distribution maps were developed for the Kraków Province in Poland (Godzik 1997) and for selected locations of in the Ukrainian Carpathian Mountains; in addition, in Kiev, Ukraine, the effects of ground-level $\mathrm{O}_{3}$ on sensitive plants (biological indicators) were described (Blum et al. 1997). Subsequently, distribution of ground-level $\mathrm{O}_{3}$ was monitored in various mountainous areas of the Czech Republic: the Sumava Mountains (Moravcik et al. 2002), Jizerske Hory (Černy et al. 2002), and the Brdy Mountains (Musselman et al. 2002). Later, as a result of the US-European collaboration, $\mathrm{O}_{3}$ distribution and evaluation of its phytotoxic potential was described for the entire Carpathian Mountains (Bytnerowicz et al. 2002), and for selected Carpathian ranges such as the Tatra Mountains (Bytnerowicz et al. 2004) and the Retezat Mountains (Bytnerowicz et al. 2001, 2005). These studies showed that the southern portion of the Carpathians in Romania, their northern section in Poland, as well as the Sumava and Brdy Mountains in the Czech Republic are characterised by low European $\mathrm{O}_{3}$ background levels (summer seasonal mean of 30 ppb). However, the western section of the Carpathians in Slovakia, sections of the eastern Ukrainian Carpathians, and the Jizerske Hory in the Czech Republic had significantly elevated concentrations with peak values exceeding 100 ppb and summer season means of $\sim 50 \mathrm{ppb}$ with a strong phytotoxic potential (Bytnerowicz et al. 2004). Elevated $\mathrm{O}_{3}$ levels in remote areas of the Czech Republic were also found by Hunova et al. (2003) who found values of the $\mathrm{O}_{3}$ exposure index, AOT40, elevated to potentially phytotoxic levels in most of the northern Czech Republic. Based on the results of air pollution monitoring in the Carpathian Mountains (Bytnerowicz et al. 2002), it was established that the combined effects of ambient $\mathrm{O}_{3}, \mathrm{SO}_{2}$, and $\mathrm{NO}_{2}$ had negative effects on the growth of Norway spruce (Picea abies) and European beech (Fagus sylvatica) in highly polluted sites (Muzika et al. 2004).

In California, the largest-scale passive sampler monitoring campaign to date was performed in summer 1999. Ozone data from 89 passive samplers and 9 real-time active monitors were gathered between May 15 and October 1 for the entire Sierra Nevada range. As collateral data, a digital elevation model (DEM) and meteorological parameters from 62 weather stations were used. Ozone distribution maps based on these data sets were developed using three different modeling approaches (Arbaugh \& Bytnerowicz 2003). The ArcGIS Geostatistical Analyst approach utilised ordinary cokriging as well as DEM and temperature, relative humidity, and precipitation as collateral data (Frączek et al. 2001, 2003). The Sierra 
Nevada passive-sampler $\mathrm{O}_{3}$ data supplemented by active monitor data from the neighboring California Central Valley was interpolated onto the surface of the DEM in conjunction with ambient temperature and loess regression to model spatial variability of the pollutant (Lee 2003), while Preisler and Schilling (2003) used the nonparametric local regression model to estimate spatial and temporal $\mathrm{O}_{3}$ changes. All of these models showed strong seasonal and spatial patterns: highest $\mathrm{O}_{3}$ concentrations occurred in the middle of summer and on the western Sierra slopes adjacent to the highly polluted Central Valley of California. The $\mathrm{O}_{3}$ distribution fields thus developed are very useful for evaluating the potential risks associated with this pollutant at the landscape and regional levels (Arbaugh \& Bytnerowicz 2003).

In 2002 the distribution of $\mathrm{O}_{3}$ and $\mathrm{HNO}_{3}$ air pollution in the Lake Tahoe Basin (Sierra Nevada in California and Nevada) was evaluated via a network of 32 sites (Fig. 1). Maximum concentrations of both pollutants were observed west of the high elevation Desolation Wilderness that prevented movement of the polluted air masses into the Lake Tahoe Basin (Gertler et al. 2006). During the same study large temporal differences in the distribution of the two pollutants were also seen, with the highest levels of both pollutants in summer when rates of photochemical reactions are the highest (Finlayson-Pitts \& Pitts 2000). Concentrations of both pollutants started to significantly decrease at the beginning of autumn (Fig. 2A-D).

A similar study was conducted in the San Bernardino Mountains of southern California during the 2002-2006 summer seasons. Concentrations of $\mathrm{O}_{3}, \mathrm{NO}_{2}, \mathrm{NH}_{3}$, and $\mathrm{HNO}_{3}$ were monitored on a network of 16 sites. Maps of $\mathrm{O}_{3}$ distribution and exposure indices of the pollutant showed that the San Bernardino Mountains have the highest levels of photochemical smog in the United States (Bytnerowicz et al. 2007, 2008). Ozone, $\mathrm{NO}_{2}$, and $\mathrm{HNO}_{3}$, major secondary pollutants and components of photochemical smog generated in the Los Angeles Basin show a very strong west to east gradient

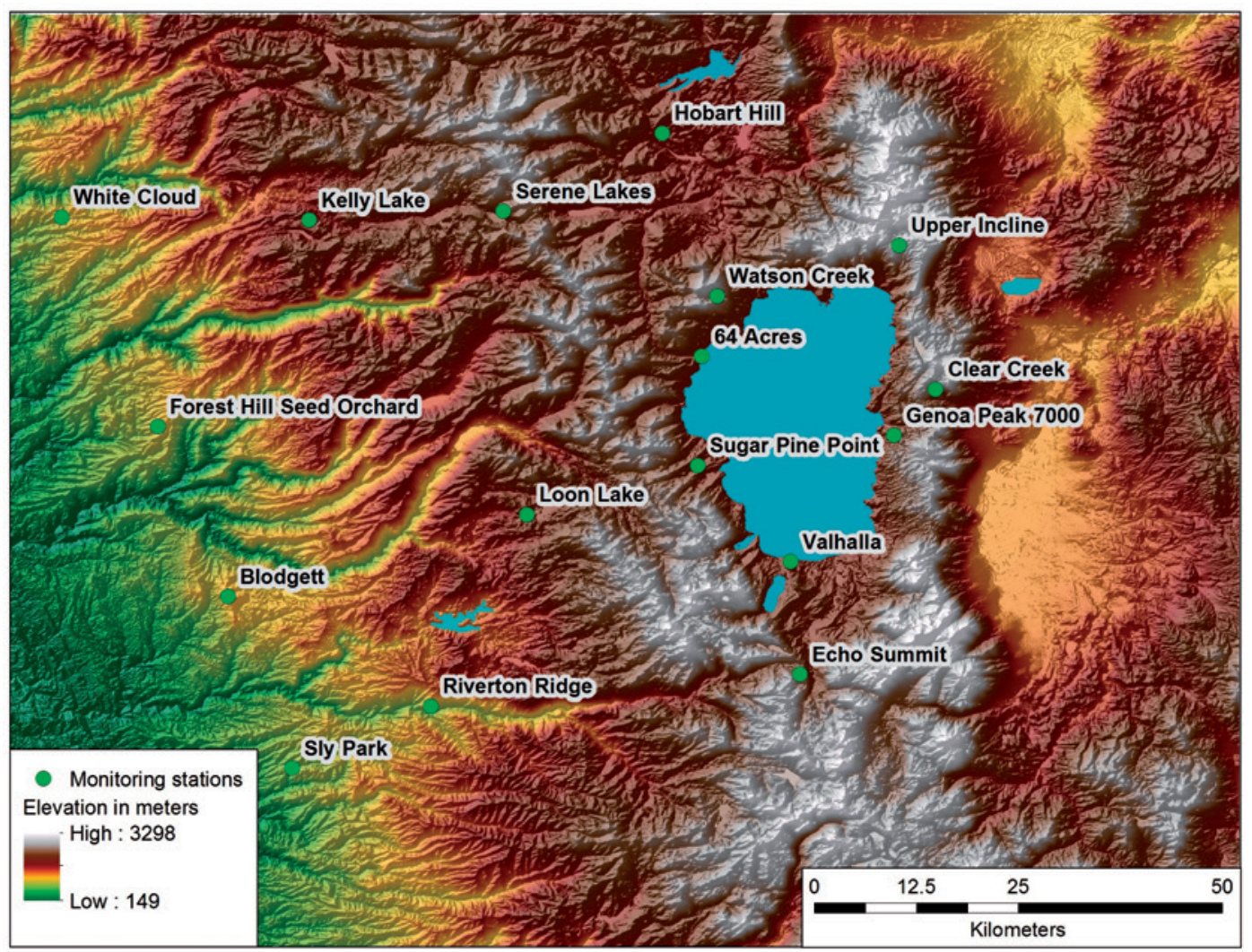

Figure 1. $\mathrm{O}_{3}$ and $\mathrm{HNO}_{3}$ monitoring network in the Lake Tahoe Basin of the Sierra Nevada in California and Nevada in 2002. 
(Fig. 3A-C). The highest concentrations of these pollutants occurred on the western edge of the range facing the Los Angeles Basin, while much lower levels were found on the eastern end of the range near the Mojave Desert. On the other hand, the spatial distribution of $\mathrm{NH}_{3}$, a primary pollutant emitted both by natural (decay of organic matter; soil emissions) and anthropogenic sources
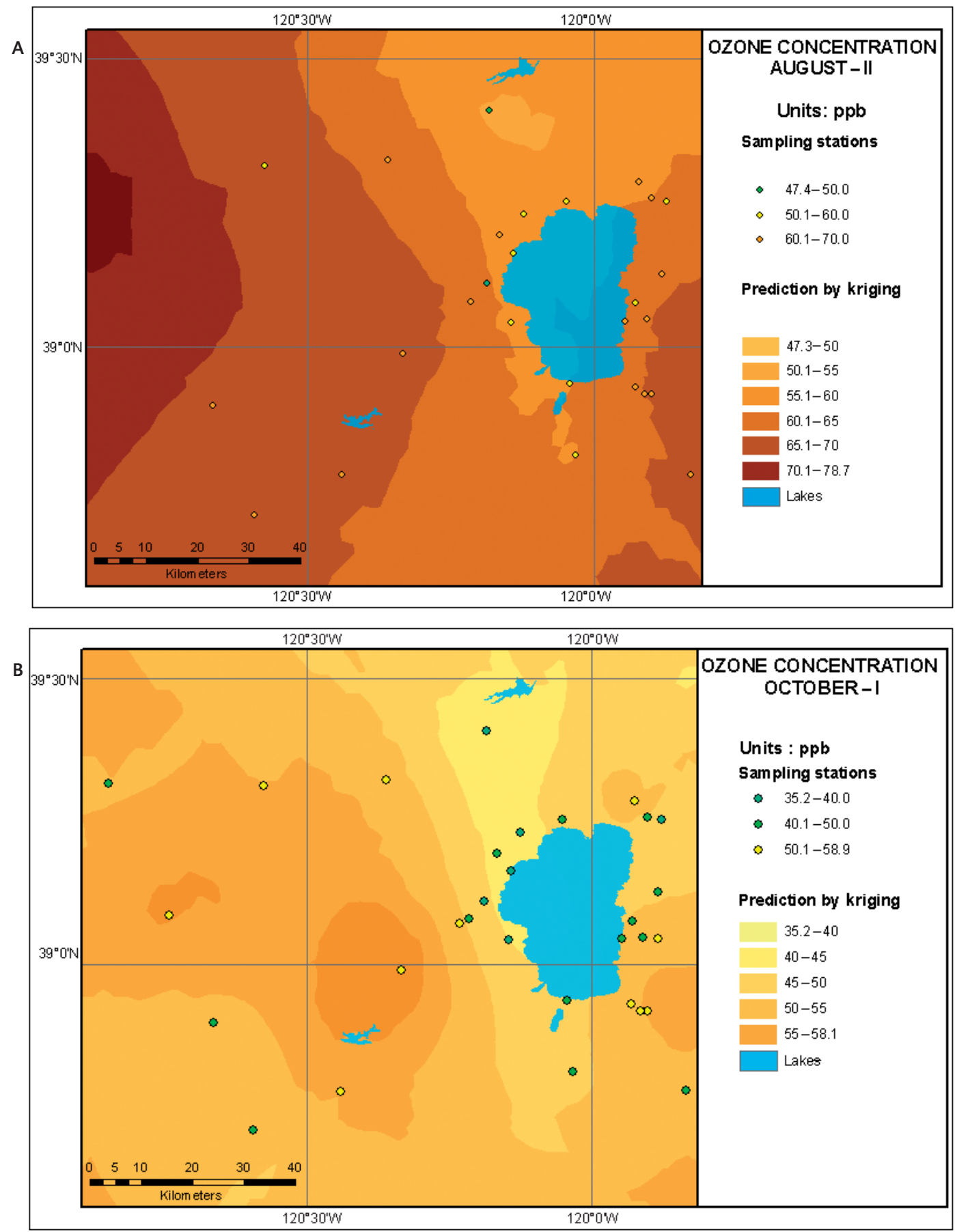

Figure 2. Distribution of air pollutants in the Lake Tahoe Basin in 2002: (A) $\mathrm{O}_{3}$ in midsummer, (B) $\mathrm{O}_{3}$ in fall. 

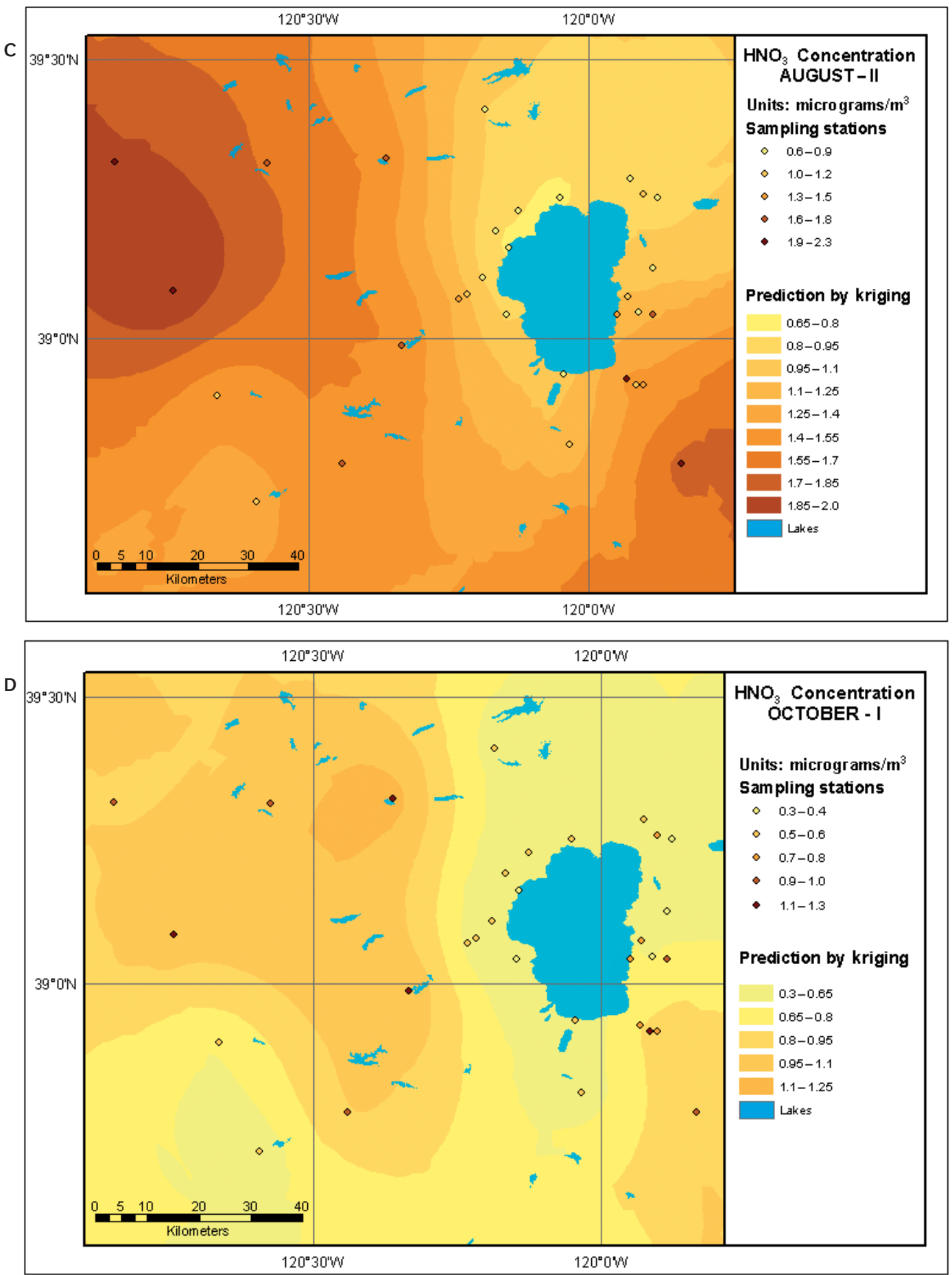

Figure 2. Distribution of air pollutants in the Lake Tahoe Basin in 2002: (C) $\mathrm{HNO}_{3}$ in midsummer, (D) $\mathrm{HNO}_{3}$ in fall.

(emissions from combustion engines equipped with catalytic converters and volatilization of fertilizers), was more complex and without a clearly defined gradient (Fig. 3D). Among the pollutants monitored, $\mathrm{HNO}_{3}$ and $\mathrm{NH}_{3}$ are strong drivers of atmospheric dry deposition and cause serious 


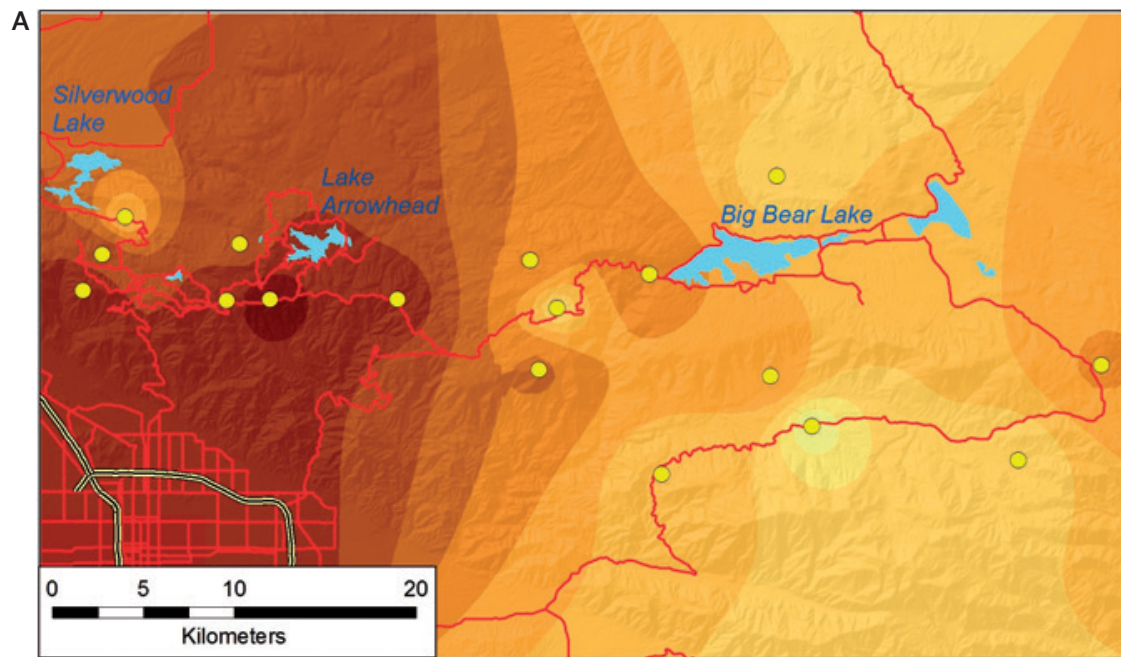

\begin{tabular}{l}
$\mathrm{O}_{3}$ Concentration \\
July $13-26,2005$ \\
Units: ppb \\
$50.6-51.8$ \\
$51.8-53.3$ \\
$53.3-55.2$ \\
$55.2-57.6$ \\
$57.6-60.7$ \\
$60.7-64.6$ \\
$64.6-69.6$ \\
$69.6-75.9$ \\
$75.9-80.9$ \\
\hline $80.9-84.8$ \\
\hline Monitoring sites 2005 \\
\hline Freeways \\
\hline Main roads
\end{tabular}
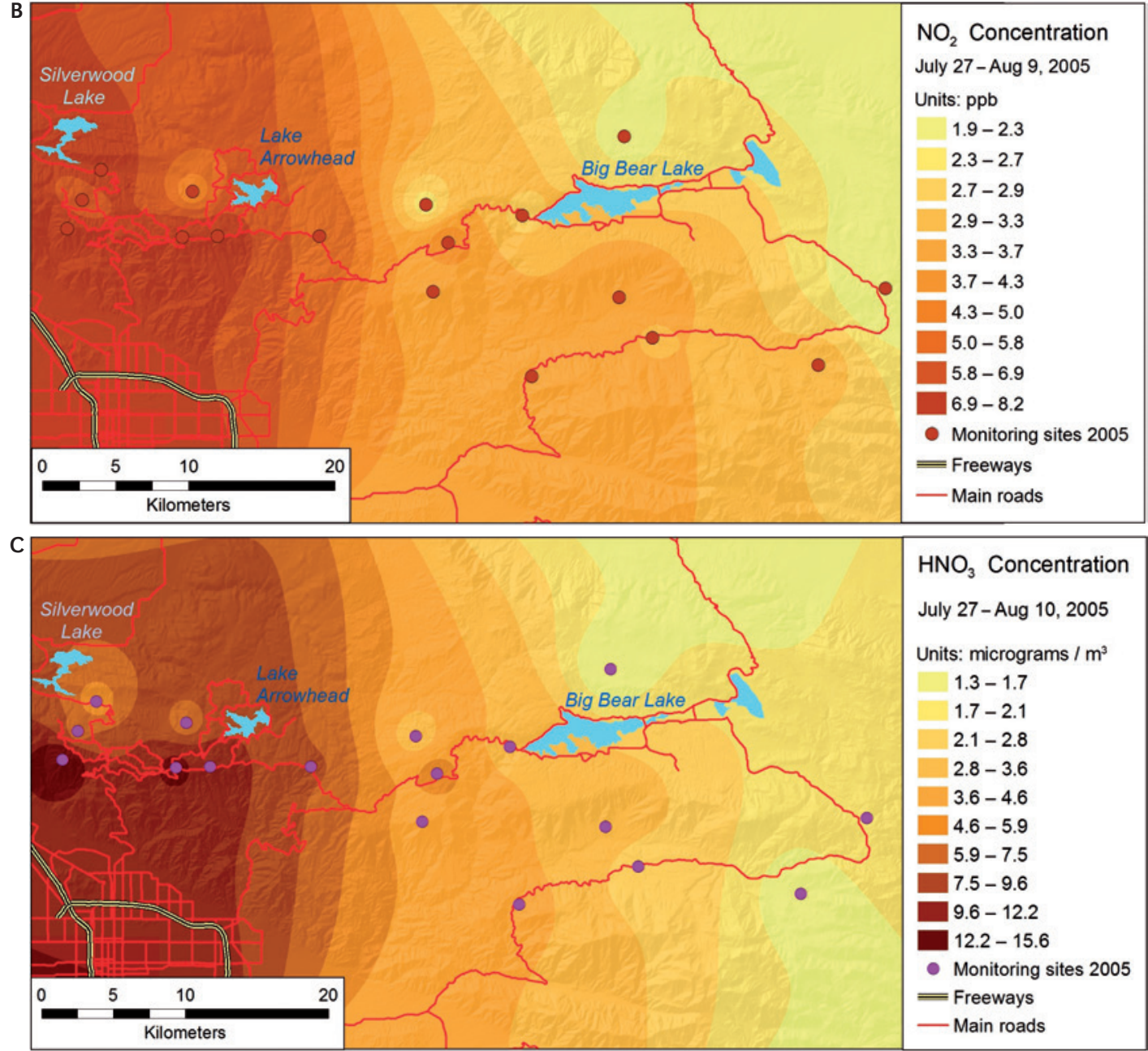

Figure 3. Distribution of air pollutants in the San Bernardino Mountains, southern California, in summer 2005: (A) $\mathrm{O}_{3}$, (B) $\mathrm{NO}_{2}$, (C) $\mathrm{HNO}_{3}$. 


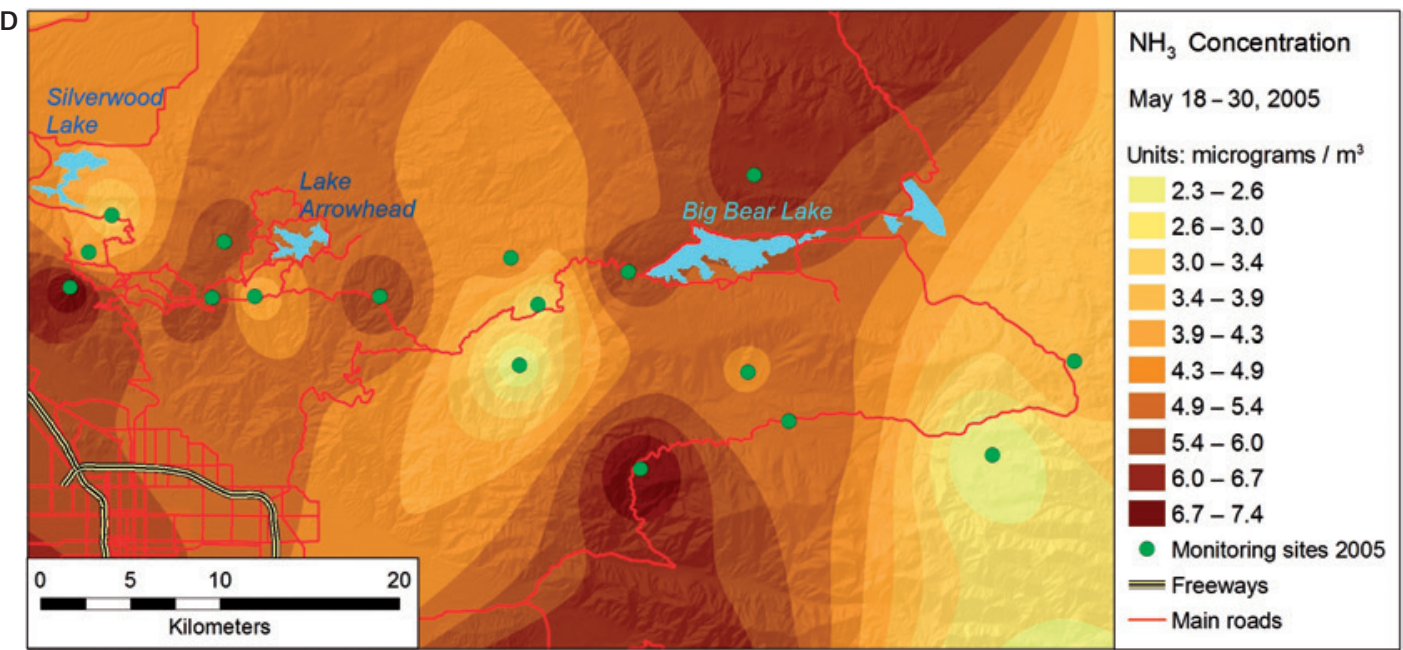

Figure 3. Distribution of air pollutants in the San Bernardino Mountains, southern California, in summer 2005: (D) $\mathrm{NH}_{3}$.

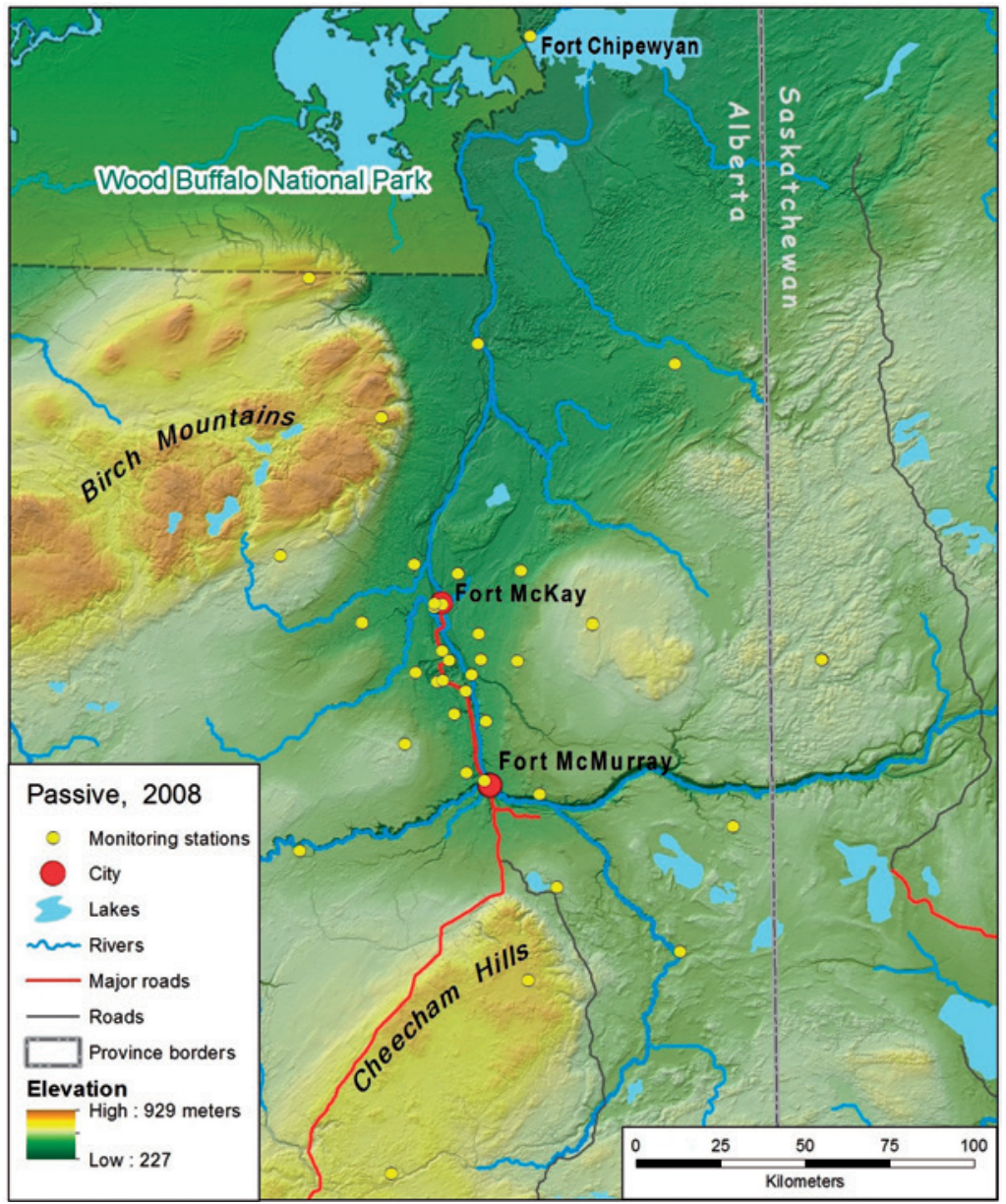

Figure 4. Air pollution monitoring network in the Athabasca Oil Sand Region, Alberta, Canada, in 2008. 
ecological effects because of their high deposition velocity and biological activity (Hanson \& Lindberg 1991).

Long-term, large-scale monitoring of $\mathrm{NH}_{3}$, $\mathrm{HNO}_{3}$, and $\mathrm{SO}_{2}$ has been conducted by the USDA Forest Service team in the Athabasca Oil Sands Region (AOSR) of northern Alberta, Canada. As an area of exploited oil sands, the rate of production and upgrading of bitumen from mining and in situ extraction as well emissions of industrial air pollutants in the AOSR have been increasing. Consequently, there is a concern that ambient concentrations of air pollutants could increase to levels causing negative effects on forests and other ecosystems in the AOSR, including ecological impacts on forests, wetlands, and lakes due to acidification and eutrophication. The monitoring network of 25 passive sampler sites was established in summer 2005, and gradually grew to 38 sites in 2009 (Fig. 4). The highest concentrations of $\mathrm{NH}_{3}$ were generally found in the centre of the AOSR industrial operations both in winter and summer, although remote sites could also exhibit high values (Fig. 5). Concentrations of $\mathrm{HNO}_{3}$ were low in winter with no significant differences between the sites. In summer, the highest $\mathrm{HNO}_{3}$ concentrations were in the centre of the AOSR and on its peripheries, far away and downwind of the AOSR industrial activities (Fig. 6). The results of the $\mathrm{SO}_{2}$ determinations for summer 2009 showed the highest levels of the pollutant reaching $8 \mu \mathrm{g} \mathrm{m}^{-3}$ at the centre of the industrial area between Fort McMurray and

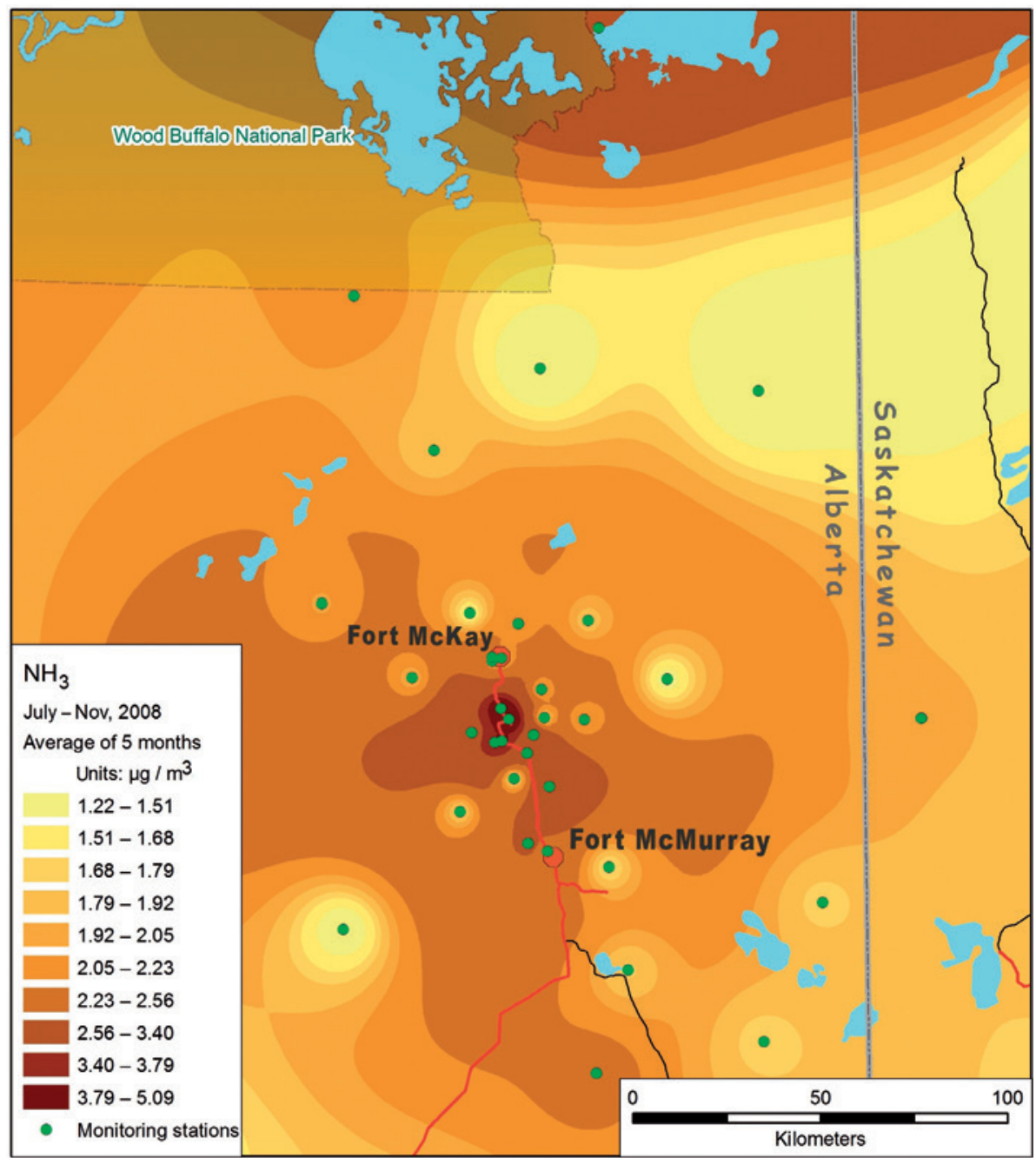

Figure 5. Distribution of $\mathrm{NH}_{3}$ concentrations in summer 2008 in the Athabasca Oil Sand Region, Alberta, Canada. 


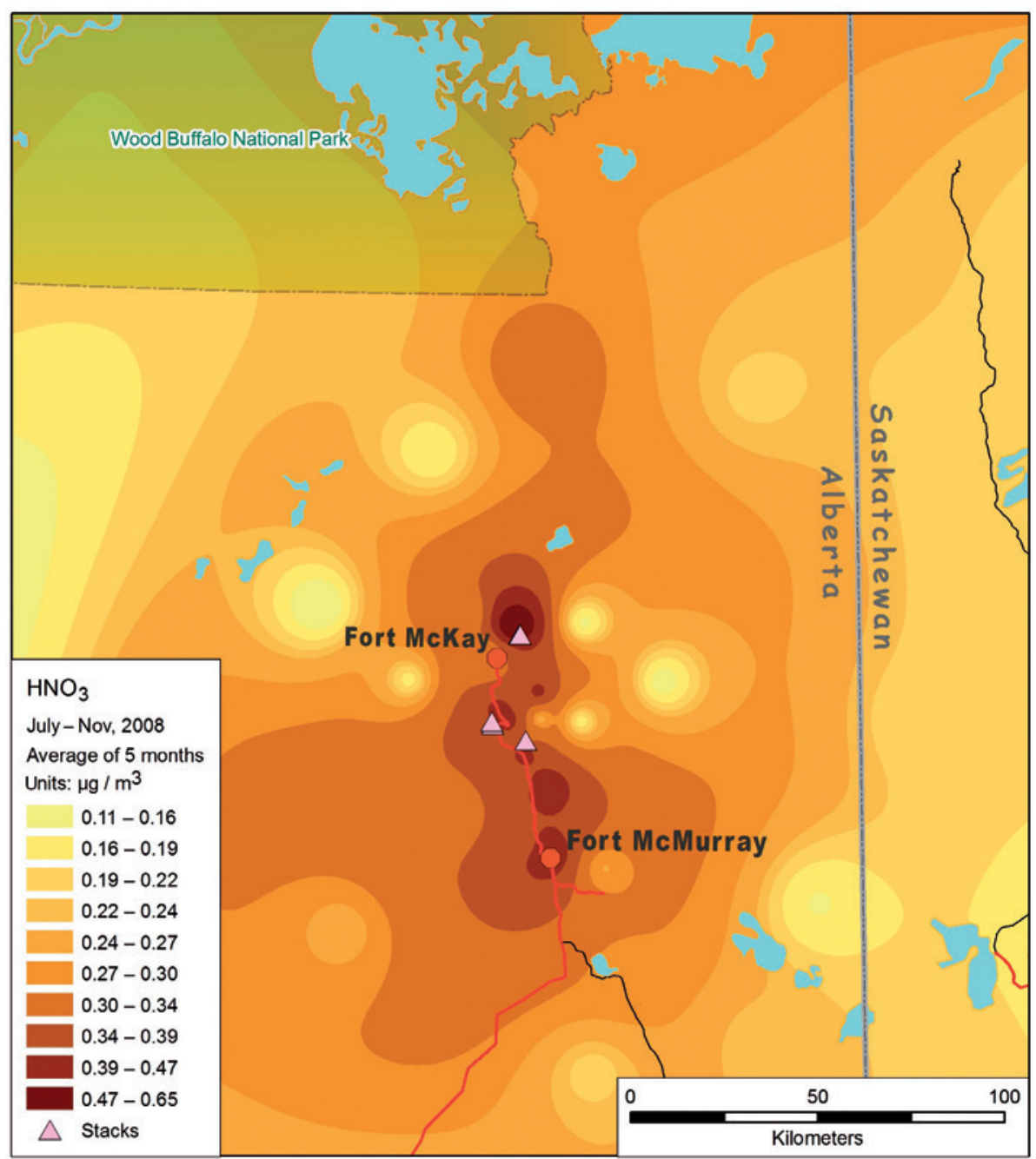

Figure 6. Distribution of $\mathrm{HNO}_{3}$ concentrations in summer 2008 in the Athabasca Oil Sand Region, Alberta, Canada.

Fort McKay, while in remote locations its concentrations were below $3 \mu \mathrm{g} \mathrm{m}^{-3}$ (Fig. 7A) (Bytnerowicz et al. 2010). An example of the uncertainty analysis of predictions was done for $\mathrm{SO}_{2}$ in summer 2009 using a combination of the prediction of standard error calculated with ordinary and simple kriging methods. The results of the uncertainty analysis indicated that additional sites installed southwest of Fort McMurray and northeast of Fort McKay would greatly improve spatial coverage of the existing monitoring network (Fig. 7B) (Bytnerowicz et al. 2010).

Combining passive sampler methodologies for monitoring air pollutants in remote areas with geostatistical methodologies for data analysis and visual presentation of the monitoring results has provided an increased understanding of pollution risks for forests and other ecosystems (Frączek et al. 2002, 2009). These methodologies have been used extensively in North America and Europe. It is planned that our approach will also be used in the rapidly developing areas in Southeast Asia and South America for a better understanding of the spatial and temporal changes in air pollution levels and their environmental threats. International collaboration through organizations such as the International Union of Forest Research Organizations or the International Cooperative Program Forests and ICP Modeling and Mapping will be utilised to accomplish this goal. 

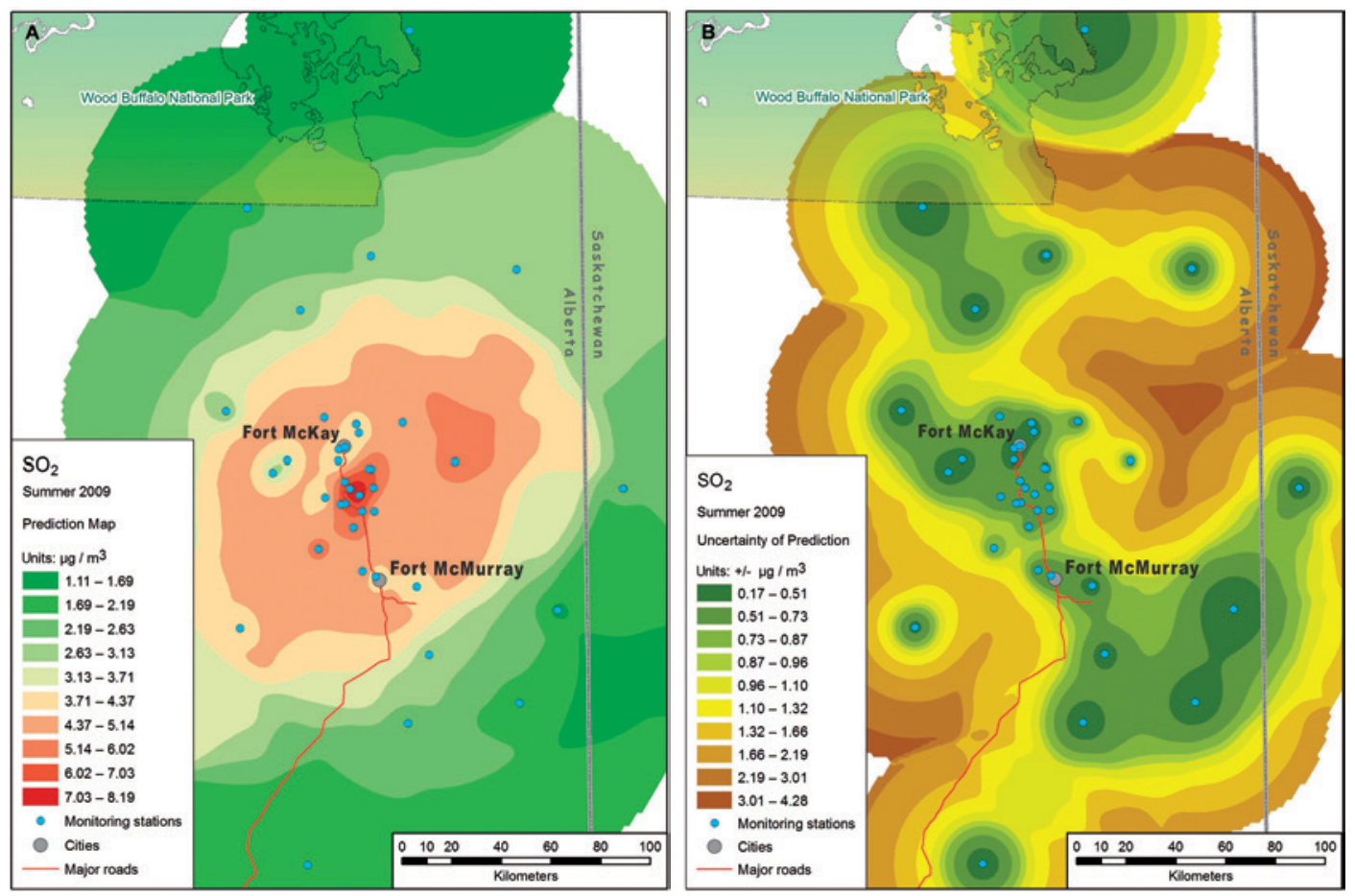

Figure 7. Distribution of $\mathrm{SO}_{2}$ concentrations in summer 2009 in the Athabasca Oil Sand Region, Alberta, Canada: (A) predictions, (B) uncertainty of predictions.

\section{Acknowledgements}

This chapter is dedicated to Prof. Alicja Breymeyer on the occasion of her eightieth birthday and celebration of her long and outstanding scientific career. It also is a token of my sincere appreciation of her devotion, enthusiasm, and energy in developing and leading the US-Central and Eastern European projects addressing the impacts of climate change and air pollution on forest ecosystems. These very productive projects allowed a fruitful collaboration among many scientists on both sides of the Atlantic.

\section{References}

Arbaugh M.J., Bytnerowicz A., 2003. Introduction to a regional passive ozone sampler network in the Sierra Nevada [in:] A. Bytnerowicz, M. Arbaugh, R. Alonso (eds.), Ozone air pollution in the Sierra Nevada. Distribution and effects on forests, Developments in Environmental Science, vol. 2, pp. 157-164.
Funding for studies described in the chapter has been provided by the USDA Agricultural Forest Service International Programs, the California Air Resources Board, the National Science Foundation Biocomplexity Grant, and the Wood Buffalo Environmental Association. The authors sincerely thank Laurie Dunne for technical editing.

Editors' note:

Unless otherwise stated, the sources of tables and figures are the author(s), on the basis of their own research.

Blum O., Bytnerowicz A., Manning W., PopoviCHEVA L., 1997. Ambient tropospheric ozone in the Ukrainian Carpathian Mountains and Kiev region: detection with passive samplers and bioindicator plants. Environmental Pollution, vol. 98, iss. 3, pp. 299-304.

BReYMeYer A., 1997. Transect studies of pine forests along parallel $52^{\circ} \mathrm{N}, 12-32^{\circ} \mathrm{E}$ and along a pollution gradient in central Europe: general assumptions, 
climatic conditions and pollution deposition. Environmental Pollution, vol. 98, iss. 3, pp. 335-346.

Bytnerowicz A. (ED.), 1997. Air pollution and climate change effects on forests in central and eastern Europe. Environmental Pollution, vol. 98, iss. 3, p. 271-398.

Bytnerowicz A., Arbaugh M., Schilling S., Fraczek W., Alexander D., Dawson P., 2007. Air pollution distribution patterns in the San Bernardino Mountains of southern California: a 40-year perspective. TheScientificWorldJOURNAL, vol. 7(S1), pp. 98-109.

Bytnerowicz A., Arbaugh M., Schilling S., Fraczek W., Alexander D., 2008. Ozone distribution and phytotoxic potential in mixed conifer forests of the San Bernardino Mountains, southern California. Environmental Pollution, vol. 155, no. 3, pp. 398-408.

Bytnerowicz A., Badea O., Popescu F., Barbu I., Postelnicu D., Vasile C., Musselman R., Manning W., Stanciu E., Tamas S., 2001. Long-term ecological research and air pollution impacts in the Retezat Mountains, Romania [in:] Long-term Ecological Research. Current state and perspectives in the Central and Eastern Europe. Proceedings of the ILTER Regional Workshop, 23-25 May, 2000, Nitra, Slovakia, Ekológia (Bratislava), vol. 20, suppl. 2, pp. 34-42.

Bytnerowicz A., Badea O., Popescu F., Musselman R., Tanase M., Barbu I., Fraczek W., Gembasu N., Surdu A., Danescu F., Postelnicu D., Cenusa R., Vasile C., 2005. Air pollution, precipitation chemistry and forest health in the Retezat Mountains, Southern Carpathians, Romania. Environmental Pollution, vol. 137, iss. 3, pp. 546-567.

Bytnerowicz A., Carroll J.J., Takemoto B.K., Miller P.R., Fenn M.E., Musselman R.C., 2000. Distribution and transport of air pollutants to vulnerable California ecosystems [in:] K.M. Scow, G.E. Fogg, D.E. Hinton, M.L. Johnson (eds.), Integrated assessment of ecosystem health, Boca Raton-London-New York-Washington: Lewis Publishers, pp. 93-118.

Bytnerowicz A., Frączek W., Grodzińska K., Godzik B., Fleischer P., Krzan Z., SkaWiński P., 2004. Distribution of ambient ozone concentrations in the forested areas of the Tatra Mountains [in:] W. Widacki, A. Bytnerowicz, A. Riebau (eds.), A Message from the Tatra. Geographical Information Systems and Remote Sensing in Mountain Environmental Research, Kraków: Jagiellonian University Press, pp. 63-75.

Bytnerowicz A., Fraczek W., Schilling S. AlexanDER D., 2010. Spatial and temporal distribution of ambient nitric acid and ammonia in the Athabasca Oil Sands Region, Alberta. Journal of Limnology, vol. 69, suppl. 1, pp. 11-21.

Bytnerowicz A., Godzik B., Fraczek W., Grodzińska K., Krywult M., Badea O., Barančok P., Blum O.,
Černy M., Godzik S., Mankovska B., Manning W. Moravčik P., Musselman R., Oszlány J., Postelnicu D., SzdZuJ J., VarŠAvova M., Zota M., 2002. Distribution of ozone and other air pollutants in forests of the Carpathian Mountains in central Europe. Environmental Pollution, vol. 116, iss. 1, pp. 3-25.

Bytnerowicz A., Godzik B., Grodzińska K., Fraczek W., Musselman R., Manning W., Badea O., Popescu F., FleisCher P., 2004. Ambient ozone in forests of the Central and Eastern European mountains. Environmental Pollution, vol. 130, iss. 1, pp. 5-16

Bytnerowicz A., Noble R.D., Breymeyer A., 1992. Effects of air pollution and climate change on forest ecosystems: a cooperative program between the United States and Central and Eastern Europe [in:] International Symposium on Environmental Contamination in Central and Eastern Europe: Budapest '92, October 12-16, 1992, Budapest, pp. 134-136.

Bytnerowicz A., Schilling S., Alexander D., FraczeK W., Hansen M., 2010. Passive monitoring to estimate $\mathrm{N}\left(\mathrm{NO}_{2}, \mathrm{HNO}_{3}, \mathrm{NH}_{3}\right)$ exposure in remote areas and geospatial analysis to optimize monitoring networks in the Athabasca Oil Sands Region. 103 Annual Conference and Exhibition of the Air \& Waste Management Association, Calgary, June 22-25, 2010, Extended Abstract 2010-A-563-AWMA.

Bytnerowicz A., Tausz M., Alonso R., Jones D., JohnSON R., GRULKe N., 2002. Summer-time distribution of air pollutants in Sequoia National Park, California. Environmental Pollution, vol. 118, iss. 2, pp. 187-203.

Černy M., Bytnerowicz A., Moravčik P., Musselman R., HOLA S., 2002. Ozone distribution and effects on plants in the Jizerske Mountains, the Czech Republic [in:] R.C. Szaro, A. Bytnerowicz, J. Oszlányi (eds.), Effects of air pollution on forest health and biodiversity in forests of the Carpathian Mountains. Proceedings of the NATO Advanced Research Workshop, Stara Lesna, Slovakia, 22-26 May 2002, NATO Science Series, Series I: Life and Behavioural Sciences, vol. 345, pp. 285-295.

EPA, 2009. Risk and exposure assessment for review of the secondary national air quality standards for oxides of nitrogen and oxides of sulfur. EPA-452/ R-09-008a, Research Triangle Park: US EPA Office of Air Quality Planning and Standards, 522 pp.

EPA, 2010. Proposal to revise the national ambient air quality standards for ozone, http://www.epa.gov/glo/ pdfs/fs20100106std.pdf [25 January 2013].

Finlayson-Pitts B.J, PitTs J.N. JR., 2000. Chemistry of the upper and lower atmosphere. Theory, experiments, and applications. San Diego: Academic Press, 969 pp.

Fowler D., Cape J.N., Coyle M., Flechard C., Kuylenstierna J., Hicks K., Derwent D., Johnson C., 
SteVENSON D., 1999. The global exposure of forests to air pollution. Water, Air, \& Soil Pollution, vol. 116, iss. 1-2, pp. 5-32.

Fraczek W., Bytnerowicz A., Arbaugh M.J., 2001. Application of the ESRI Geostatistical Analyst for determining the adequacy and sample size requirements of ozone distribution models in the Carpathian and Sierra Nevada Mountains. TheScientificWorld, vol. 1, pp. 836-854.

Frączek W., Bytnerowicz A., Arbaugh M.J., 2003. Use of geostatistics to estimate surface ozone patterns [in:] A. Bytnerowicz, M. Arbaugh, R. Alonso (eds.), Ozone air pollution in the Sierra Nevada. Distribution and effects on forests, Developments in Environmental Science, vol. 2, pp. 215-247.

Fraczzek W., Bytnerowicz A., Legge A.H., 2009. Optimizing a monitoring network for assessing ambient air quality in the Athabasca Oil Sands Region of Alberta, Canada [in:] R. Jandl, A. Borsdorf, H. van Miegroet, R. Lackner, R. Psenner (eds.), Global Change and Sustainable Development in Mountain Regions, Alpine Space - Man \& Environment, vol. 7, Innsbruck: University Press, pp. 127-142.

Fraczek W., Postelnicu D., Bytnerowicz A., Černy M., VASILE C., 2002. GIS as a tool for evaluating air pollution and biological resources of Carpathian forests [in:] R.C. Szaro, A. Bytnerowicz, J. Oszlányi (eds.), Effects of air pollution on forest health and biodiversity in forests of the Carpathian Mountains. Proceedings of the NATO Advanced Research Workshop, Stara Lesna, Slovakia, 22-26 May 2002, NATO Science Series, Series I: Life and Behavioural Sciences, vol. 345, pp. 121-137.

Galloway J.N., Aber J.D., Erisman J.W., Seitzinger S.P., Howarth R.W., Cowling E.B., Cosby B.J., 2003. The nitrogen cascade. BioScience, vol. 53, no. 4, pp. 341-356.

Gertler A.W., Bytnerowicz A., Cahill T.A., Arbaugh M., Cliff S., Kahyaoglu-Koračin J., Tarnay L., Alonso R., Fraczek W., 2006. Local air pollutants threaten Lake Tahoe's clarity. California Agriculture, vol. 60, no. 2, pp. 53-58.

GodzIK B., 1997. Ground level ozone concentrations in the Krakow region, southern Poland. Environmental Pollution, vol. 98, iss. 3, pp. 273-280.

Hanson P.J., LindBerg S.E., 1991. Dry deposition of reactive nitrogen compounds. A review of leaf, canopy and non-foliar measurements. Atmospheric Environment. Part A. General Topics, vol. 25, iss. 8, pp. 1615-1634.

HŮNOVÁ I., 2003. Ambient air quality for the territory of the Czech Republic in 1996-1999 expressed by three essential factors. The Science of the Total Environnment, vol. 303, pp. 245-251.
Johnston K., Ver Hoef J.M., KrivoruchKo K., LuCAS N., 2001. Using Arc GIS Geostatistical Analyst. Redlands: Environmental Systems Research Institute, 300 pp.

Koutrakis P., Wolfson J.M., Bunyaviroch A., Froelich S.E., Hirano K., Mulik J.D., 1993. Measurement of ambient ozone using a nitrite-saturated filter. Analytical Chemistry, vol. 65, pp. 210-214.

LEE E.H., 2003. Use of auxiliary data for spatial interpolation of surface ozone patterns [in:] A. Bytnerowicz, M. Arbaugh, R. Alonso (eds.), Ozone air pollution in the Sierra Nevada. Distribution and effects on forests. Developments in Environmental Science, vol. 2, pp. 165-194.

Legge A.H., JÄGER H.-J., KRupa S.V., 1998. Sulfur dioxide [in:] R.B. Flagler (ed.), Recognition of air pollution injury to vegetation. A pictorial atlas, Pittsburgh: Air \& Waste Management Association, pp. 3-42.

Millán M.M., Salvador R., Mantilla E., KalLOS G., 1997. Photooxidant dynamics in the Mediterranean basin in summer: Results from European research projects. Journal of Geophysical Research: Atmospheres, vol. 102, iss. D7, pp. 8811-8823.

Miller P.R., 1992. Mixed conifer forests of the San Bernardino Mountains, California [in:] R. Olson, D. Binkley, M. Böhm (eds.), The response of western forests to air pollution, Ecological Studies, vol. 97, New York: Springer Verlag, pp. 461-497.

Miller P.R., de Bauer M.L., Nolasco A.Q., Tejeda T.H., 1994. Comparison of ozone exposure characteristics in forested regions near Mexico City and Los Angeles. Atmospheric Environment, vol. 28, iss. 1, pp. 141-148.

MoravčIK P., Bytnerowicz A., Černy M., Musselman R., 2002. Ozone distribution and effects in the Šumava Mountains, Czech Republic [in:] R.C. Szaro, A. Bytnerowicz, J. Oszlányi (eds.), Effects of air pollution on forest health and biodiversity in forests of the Carpathian Mountains. Proceedings of the NATO Advanced Research Workshop, Stara Lesna, Slovakia, 22-26 May 2002, NATO Science Series, Series I: Life and Behavioural Sciences, vol. 345, pp. 304-312.

Musselman R., Moravčik P., Bytnerowicz A., Zeller K., ČERnY M., 2002. Ambient ozone and plant responses in the Brdy Mountains, Czech Republic [in:] R.C. Szaro, A. Bytnerowicz, J. Oszlányi (eds.), Effects of air pollution on forest health and biodiversity in forests of the Carpathian Mountains. Proceedings of the NATO Advanced Research Workshop, Stara Lesna, Slovakia, 22-26 May 2002, NATO Science Series, Series I: Life and Behavioural Sciences, vol. 345, pp. 296-303.

Muzika R.M., Guyette R.P., Zielonka T., Liebhold A.M., 2004. The influence of $\mathrm{O}_{3}, \mathrm{NO}_{2}$ and $\mathrm{SO}_{2}$ on growth of Picea abies and Fagus sylvatica in the Carpathian Mountains. Environmental Pollution, vol. 130, iss. 1, pp. 65-71. 
Neufeld H.S., Peoples S.J., Davison A.W., Chappelka A.H., Somers G.L., Thomley J.E., Booker F.L., 2012. Ambient ozone effects on gas exchange and total non-structural carbohydrate levels in cutleaf coneflower (Rudbeckia laciniata L.) growing in Great Smoky Mountains National Park. Environmental Pollution, vol. 160, pp. 74-81.

OgawA, 2006. $\mathrm{NO}, \mathrm{NO}_{2}, \mathrm{NO}_{x}$ and $\mathrm{SO}_{2}$ sampling protocol using the Ogawa sampler. Pompano Beach: Ogawa \& Co., 30 pp.

Padgett P.E., Allen E.B., Bytnerowicz A., Minnich R.A., 1999. Changes in soil inorganic nitrogen as related to atmospheric nitrogenous pollutants in southern California. Atmospheric Environment, vol. 33, pp. 769-781.

Preisler H.K., Schilling S., 2003. Use of nomparametric local regression to estimate surface ozone patterns over space and time [in:] A. Bytnerowicz, M. Arbaugh, R. Alonso (eds.), Ozone air pollution in the Sierra Nevada. Distribution and effects on forests, Developments in Environmental Science, vol. 2, pp. 195-214.

Seinfeld J.H., Pandis S.N., 1999. Atmospheric chemistry and physics. From air pollution to climate change. New York: Wiley, 1326 pp.

Sitch S., Cox P.M., Coluins W.J., Huntingford C., 2007. Indirect radiative forcing of climate change through ozone effects on the land-carbon sink. Nature, vol. 448, iss. 7155, pp. 791-794.

Wang X., Mauzerall D.L., 2004. Characterizing distributions of surface ozone and its impact on grain production in China, Japan and South Korea: 1990 and 2020. Atmospheric Environment, vol. 38, pp. 4383-4402. 